\title{
Mouse hypothalamic GT1-7 cells demonstrate AMPK-dependent intrinsic glucose-sensing behaviour
}

\author{
C. Beall • D. L. Hamilton • J. Gallagher • L. Logie • \\ K. Wright • M. P. Soutar $\cdot$ S. Dadak • F. B. Ashford • \\ E. Haythorne • Q. Du • A. Jovanović • \\ R. J. McCrimmon • M. L. J. Ashford
}

Received: 16 January 2012 / Accepted: 21 May 2012 /Published online: 4 July 2012

(C) The Author(s) 2012. This article is published with open access at Springerlink.com

\begin{abstract}
Aims/hypothesis Hypothalamic glucose-excited (GE) neurons contribute to whole-body glucose homeostasis and participate in the detection of hypoglycaemia. This system appears defective in type 1 diabetes, in which hypoglycaemia commonly occurs. Unfortunately, it is at present unclear which molecular components required for glucose sensing are produced in individual neurons and how these are functionally linked. We used the GT1-7 mouse hypothalamic cell line to address these issues.

Methods Electrophysiological recordings, coupled with measurements of gene expression and protein levels and activity, were made from unmodified GT1-7 cells and cells in which AMP-activated protein kinase (AMPK) catalytic subunit gene expression and activity were reduced.

Results Hypothalamic GT1-7 neurons express the genes encoding glucokinase and ATP-sensitive $\mathrm{K}^{+}$channel $\left(\mathrm{K}_{\mathrm{ATP}}\right)$ subunits $K_{i r} 6.2$ and Surl and exhibit GE-type glucosesensing behaviour. Lowered extracellular glucose concentration hyperpolarised the cells in a concentration-dependent manner, an outcome that was reversed by tolbutamide. Inhibition of glucose uptake or metabolism hyperpolarised cells, showing that energy metabolism is required to main-
\end{abstract}

Electronic supplementary material The online version of this article (doi:10.1007/s00125-012-2617-y) contains peer-reviewed but unedited supplementary material, which is available to authorised users.

C. Beall • D. L. Hamilton · J. Gallagher $\cdot$ L. Logie $\cdot$ K. Wright $•$ M. P. Soutar $\cdot$ S. Dadak $\cdot$ F. B. Ashford $\cdot$ E. Haythorne $\cdot$ Q. Du A. Jovanović • R. J. McCrimmon • M. L. J. Ashford ( $\triangle$ )

Medical Research Institute, Division of Cardiovascular \& Diabetes

Medicine, Ninewells Hospital \& Medical School,

University of Dundee,

Dundee DD1 9SY, UK

e-mail: m.1.j.ashford@dundee.ac.uk tain their resting membrane potential. Short hairpin (sh)RNA directed to Ampka2 (also known as Prkaa2) reduced GT1-7 cell AMPK $\alpha 2$, but not AMPK $\alpha 1$, activity and lowered the threshold for hypoglycaemia-induced hyperpolarisation. shAmpk 1 (also known as Prkaal) had no effect on glucose-sensing or AMPK $\alpha 2$ activity. Decreased uncoupling protein 2 (Ucp2) mRNA was detected in AMPK $\alpha 2$ reduced cells, suggesting that AMPK $\alpha 2$ regulates UCP2 levels.

Conclusions/interpretation We have demonstrated that GT1-7 cells closely mimic GE neuron glucose-sensing behaviour, and reducing AMPK $\alpha 2$ blunts their responsiveness to hypoglycaemic challenge, possibly by altering UCP2 activity. These results show that suppression of AMPK $\alpha 2$ activity inhibits normal glucose-sensing behaviour and may contribute to defective detection of hypoglycaemia.

Keywords AMPK · Glucokinase · Glucose sensing · GT1-7 cells $\cdot$ Hypoglycaemia $\cdot$ Hypothalamus $\cdot \mathrm{K}_{\mathrm{ATP}} \cdot \mathrm{UCP} 2$

$\begin{array}{ll}\text { Abbreviations } \\ \text { ACC } & \text { Acetyl-CoA carboxylase } \\ \text { AMPK } & \text { AMP-activated protein kinase } \\ \text { GCK } & \text { Glucokinase } \\ \text { GE } & \text { Glucose excited } \\ \text { GI } & \text { Glucose inhibited } \\ \text { GnRH } & \text { Gonadotrophin-releasing hormone } \\ \mathrm{K}_{\text {ATP }} & \text { ATP-sensitive } \mathrm{K}^{+} \text {channel } \\ \mathrm{K}_{\text {ir }} & \text { Inwardly rectifying } \mathrm{K}^{+} \text {channel } \\ \text { POMC } & \text { Proopiomelanocortin } \\ \text { shCont } & \text { Control shRNA } \\ \text { shRNA } & \text { Short-hairpin RNA } \\ \text { SUR1 } & \text { Sulfonylurea receptor 1 } \\ \text { UCP2 } & \text { Uncoupling protein 2 }\end{array}$




\section{Introduction}

The ability of the hypothalamus to sense change in glucose levels is important in the control of feeding, energy expenditure and peripheral glucose homeostasis in mammals. Indeed, for patients with type 1 diabetes, the impairment of central detection of reduced glucose levels (hypoglycaemic unawareness) is a major concern, as this results in a defective counter-regulatory response, leading to severe risk of profound hypoglycaemia and consequent morbidities [1]. Although brain glucose concentrations parallel those of plas$\mathrm{ma}$, they are generally much lower. Thus, during euglycaemia, brain glucose concentrations are $\sim 1.0-2.5 \mathrm{mmol} / \mathrm{l}$ and, during extreme hyperglycaemia or hypoglycaemia, may reach 5 and $0.2 \mathrm{mmol} / \mathrm{l}$, respectively [2]. To detect changes in brain glucose levels and produce proportionate physiological responses, a neuronal glucose-sensing system is required. Brain regions intimately associated with this role are the hypothalamus, amygdala, basal ganglia and hindbrain, where specific neuron subtypes that respond electrically to acute variations in glucose are situated [3]. The two major subtypes are glucose-excited (GE) and glucoseinhibited (GI) neurons, whereby a hypoglycaemic stimulus results in hyperpolarisation and inhibition and depolarisation and excitation, respectively [3, 4].

The identity of the molecular constituents that confer glucose-sensing properties on these neurons is unclear. This is due to the difficulties associated with intact brain tissue, absence of a transgenic mouse model allowing easy location of glucose-sensing neurons, uncertainties regarding the role of astrocytes, and lack of a suitable cell culture model. Although GE neurons exhibit similar glucose-sensing behaviour to pancreatic beta cells, the glucose concentration range over which electrical responses occur deviates significantly. The responsiveness of beta cells to altered plasma glucose is dependent on the presence of: GLUT2 in rodents (GLUT1 in humans), the high-capacity glucose transporter; GCK, the low-affinity hexokinase isoform, glucokinase; and $\mathrm{K}_{\mathrm{ATP}}$, the ATP-sensitive $\mathrm{K}^{+}$channel, consisting of the $\mathrm{K}^{+}$channel subunit, $\mathrm{K}_{\mathrm{ir}} 6.2$, and the sulfonylurea receptor, SUR1 [5]. All four proteins are produced in hypothalamic cells, but not always in a coincident manner and in conjunction with unequivocal identification of glucose-sensing properties [6, 7]. Thus there is no clear consensus about the molecular definition of glucose sensing in GE neurons. Our knowledge of the molecular constituents that underlie GI neuron glucose-sensing behaviour is even less well advanced [8]. In addition, glucose sensing may not be an intrinsic feature of hypothalamic neuron populations, but may require metabolic support from glial cells, particularly astrocytes $[1,6]$.

Recent studies have shown that AMP-activated protein kinase (AMPK) is an essential component for detection of hypoglycaemia by pancreatic beta cells and hypothalamic neurons. Thus ablation of the AMPK $\alpha 2$ catalytic subunit from beta cells [9] and subpopulations of GE hypothalamic neurons [10] results in failure of these cells to respond electrically to reduced levels of glucose. Importantly, hypothalamic AMPK plays a key role in the integrative response to central hypoglycaemia detection, with AMPK downregulation suppressing [11], and activation amplifying [12], counter-regulatory responses, respectively.

We show that mouse hypothalamic GT1-7 cells [13] exhibit hypoglycaemia-detecting behaviour typical of GE neurons and utilise a similar array of molecular components to beta cells to elicit an electrical response. Furthermore, like native hypothalamic neuron and beta cell glucose sensors, GT1-7 cells exhibit dependence on AMPK $\alpha 2$ activity for the transduction of a hypoglycaemic signal to an electrical response.

\section{Methods}

Cell culture GT1-7 cells (Pamela Mellon, San Diego, California, USA [13]) were maintained in DMEM (SigmaAldrich, Gillingham, UK) with 10\% FBS (PAA Laboratories, Yeovil, UK) as previously described [14].

Immunoblotting GT1-7 cells, in six-well dishes, were serum-starved for $3 \mathrm{~h}$, and DMEM (low or high glucose) was replaced with normal saline (below) before challenge with glucose. Protein isolation and immunoblotting procedures were as described previously [14]. Briefly, protein lysates were subjected to SDS-PAGE and electrotransferred to nitrocellulose membrane, and immunoreactive proteins were identified by chemiluminescence. Primary antibodies used were: phospho-AMPK (Thr172; 1:1000 dilution) and phosphorylated acetyl-CoA carboxylase (p-ACC; Ser79; 1:1000 dilution) from New England Biolabs, Hitchin, UK; AMPK $\alpha 2$ and AMPK $\alpha 1$ from D.G. Hardie, University of Dundee, Dundee, UK; GK from M. Magnusson, Vanderbilt University, Nashville, Tennessee, USA; $\mathrm{K}_{\mathrm{ir}} 6.2$ (p-Ser385) from L.M. Chuang, Taipei, Taiwan; actin (1:5000 dilution) from Sigma-Aldrich. Gel protein bands were quantified by densitometry, where total density was determined with respect to a constant area, the background was subtracted, and the average relative band density was calculated.

Assay of AMPK activity GT1-7 cells were maintained in $2.5 \mathrm{mmol} / \mathrm{lglucose} / \mathrm{DMEM}$ and serum and washed in normal saline $(2.5 \mathrm{mmol} / \mathrm{l}$ glucose $)$, before challenge with 2.5 or $0.5 \mathrm{mmol} / \mathrm{l}$ glucose for various times. Cells were lysed in lysis buffer (in mmol/l: 50 Tris-HCl, pH 7.5, $150 \mathrm{NaCl}, 50 \mathrm{NaF}$, 5 sodium pyrophosphate, 1 EDTA, 1 EGTA, 1 dithiothreitol, 
0.1 benzamidine) with $0.1 \mathrm{mmol} / 1$ phenylmethanesulfonyl fluoride, $5 \mu \mathrm{g} / \mathrm{ml}$ soya bean trypsin inhibitor and 1\% (vol./ vol.) Triton X-100, and the protein content was determined (BCA assay; Fisher Scientific, Loughborough, UK). AMPK activity was determined as previously described [15] by calculating the difference in counts between AMARA (AMPK substrate: AMARAASAAALARRR)-containing and AMARA-negative samples as nmol ATP incorporated per min per mg peptide. Data were normalised to the control and are expressed as the mean of four to six independent experiments each with three replicates.

AMPK knockdown Lentiviral transduction of cells using non-targeting short hairpin RNA (shRNA; control; SHC202; Sigma-Aldrich) and shRNA targeting Ampkol (also known as Prkaal) and Ampko2 (also known as Prkaa2) was performed as per the manufacturer's instructions. Briefly, GT1-7 cells were grown in poly-L-lysinecoated 12 -well dishes to $\sim 50 \%$ confluence. Hexadimethrine bromide $(10 \mu \mathrm{g} / \mathrm{ml})$ and $40 \mu l$ lentiviral particles were added to each well, and, after $24 \mathrm{~h}$, the mixture was replaced with fresh medium. Cells were grown to $\sim 80 \%$ confluence and selected using puromycin hydrochloride $(5 \mu \mathrm{g} / \mathrm{ml})$. All data presented are from three to four independent cell lines, each generated in parallel to a control, and comparisons are between the knockdown line of interest and their control. Knockdown of AMPK $\alpha 1$ and AMPK $\alpha 2$ was screened by western blot and assay of radiolabelled kinase activity. A panel of five clones targeting AMPK $\alpha 1$ and AMPK $\alpha 2$ was used for screening, with clones XM_139298.4-1396s1c1 $(\mathrm{AMPK} \alpha 1)$ and XM_131633.3-858s1c1 (AMPK $\alpha 2)$ providing the best knockdown.

Gene expression studies mRNA was quantified using realtime quantitative RT-PCR as described previously $[9,16]$. mRNA was extracted from GT1-7 cells or mouse brain, heart or liver using Tri reagent (Sigma-Aldrich) according to the manufacturer's protocol. cDNA was prepared using $1 \mu \mathrm{g}$ RNA reverse transcribed with Superscript II kit (Life Technologies, Paisley, UK) or ImProm-II reverse transcriptase (Promega, Madison, WI, USA) with oligo(dT) priming and RNase treatment. mRNA expression was analysed using an ABI Prism 7500 or ABI 7700 sequence detection system (Applied Biosystems, Foster City, CA, USA) or an iCycler iQ TM Multicolor Real-Time system (Bio-Rad, Hercules, CA, USA) using primer/probe sets designed (Applied Biosystems, Paisley, UK) to target Slc2a1, Slc2a2, Slc2a3, Slc2a4 (solute carrier family 2 [facilitated glucose transporters 1-4]), Hk1, Hk2, Hk3 and Gck, Slc16a7 (neuronal monocarboxylate transporter), $A b c c 8, A b c c 9$ (sulfonylurea receptors 1 and 2), and Kcnj8 and Kcnj11 ( $\mathrm{K}_{\mathrm{ir}} 6.1$ and $\mathrm{K}_{\mathrm{ir}} 6.2$ ), and data were analysed by the $2^{-\Delta \mathrm{C}_{\mathrm{t}}}$ method
[16]. Levels of Ucp 2 mRNA under control and AMPK $\alpha 2$ knockdown are expressed relative to 18S RNA. For detection of Gck mRNA, tissues were homogenised in Trizol reagent, and $1 \mu \mathrm{g}$ RNA reverse transcribed as above. PCR was carried out with first-strand cDNA with primers for mouse pancreas-type GCK (forward, TGGAGGCCACCAAGAAGGAAAAG; reverse, GCATCTCGGAGAAGTCCCACGATG).

Electrophysiology GT1-7 cells were superfused at room temperature $\left(22-25^{\circ} \mathrm{C}\right)$ with saline (in $\left.\mathrm{mmol} / \mathrm{l}\right): 135 \mathrm{NaCl}$, $5 \mathrm{KCl}, 1 \mathrm{MgCl}_{2}, 1 \mathrm{CaCl}_{2}, 10$ HEPES, 10 or 2.5 glucose ( $\mathrm{pH}$ 7.4). Membrane potentials were recorded using perforatedpatch or whole-cell current-clamp configurations, and currents by whole-cell voltage clamp. In whole-cell experiments, cells were maintained in current-clamp mode to monitor resting membrane potential, with short excursions into voltage clamp to obtain current-voltage relations. Current- and voltage-clamp data were collected and analysed as described previously [9]. Recording electrodes had resistances of 5-10 M $\Omega$ when filled with pipette solution, which for whole-cell recordings comprised (in mmol/l) $140 \mathrm{KCl}, 5 \mathrm{MgCl}_{2}, 3.8 \mathrm{CaCl}_{2}, 10$ EGTA, 10 HEPES, pH 7.2 (free $\left[\mathrm{Ca}^{2+}\right]$ of $100 \mathrm{nmol} / \mathrm{l}$ ). For perforated-patch recordings, the electrode solution contained (in mmol/l): $140 \mathrm{KCl}, 5$ $\mathrm{MgCl}_{2}, 3.8 \mathrm{CaCl}_{2}, 10$ HEPES, 10 EGTA (pH 7.2) and 25$40 \mu \mathrm{g} / \mathrm{ml}$ amphotericin B (Sigma-Aldrich). After a minimum of 10 min of stable recording, normal saline containing altered glucose concentration and/or tolbutamide (100 $\mu \mathrm{mol} / \mathrm{l})$, diazoxide $(250 \mu \mathrm{mol} / \mathrm{l})$ (both SigmaAldrich) or NN414 (5 $\mu \mathrm{mol} / \mathrm{l}$; Novo Nordisk, Copenhagen, Denmark) was applied.

Statistical analysis Data are presented as means \pm SEM. Analysis of variance, one-sample $t$ test and Student's paired or unpaired $t$ tests were performed using GraphPad Prism (Prism 5) software (GraphPad Software, La Jolla, CA, USA). $p$ values $\leq 0.05$ were considered statistically significant.

\section{Results}

Expression of GT1-7 cell glucose transporter, hexokinase and functional $K_{A T P}$ channel subunits GT1-7 cells show mRNA for the glucose transporters Glut1, Glut3 and Glut4, but not Glut2 (Fig. 1a) and for the monocarboxylate transporter, Slcl6a7 (data not shown). mRNAs for $H k 1$ and $H k 2$, but not $H k 3$ or Gck, could be distinguished (Fig. 1a). In further attempts to demonstrate Gck mRNA, PCR was performed using pancreas-specific Gck mRNA primers, and expression of this transcript was confirmed, with GCK 
protein also detectable by immunoblot in GT1-7 cells (Fig 1b,c). Sulfonylurea receptor subunit Sur1 mRNA was expressed, with Sur $2 b$ mRNA also present, along with the pore-forming $\mathrm{K}_{\mathrm{ATP}}$ subunit $K_{i r} 6.2$ (with protein also detectable by immunoblot; electronic supplementary material [ESM] Fig. 1), although no $K_{i r} 6.1$ or Sur $2 a$ mRNA was demonstrable (Fig. 1d). Perforated-patch recordings revealed electrical activity in saline containing 10 or $2.5 \mathrm{mmol} / 1$ glucose, with no difference in firing rates or membrane potential $\left(V_{\mathrm{m}}\right)\left(10 \mathrm{mmol} / \mathrm{l}, V_{\mathrm{m}}=-51.0 \pm 2.5 \mathrm{mV}\right.$ $\left.[n=8] ; 2.5 \mathrm{mmol} / 1, V_{\mathrm{m}}=-48.8 \pm 2.2 \mathrm{mV}[n=5] ; p>0.1\right)$. GT1-7 cells in $10 \mathrm{mmol} / 1$ glucose and challenged with $2.5 \mathrm{mmol} / \mathrm{l}$ glucose also showed no change in $V_{\mathrm{m}}$ or firing rate (data not shown). For cells in $2.5 \mathrm{mmol} / 1$ glucose, addition of tolbutamide $(200 \mu \mathrm{mol} / \mathrm{l})$ caused a modest depolarisation $(<3 \mathrm{mV})$ and increased firing (Fig. 1e). In contrast, the $\mathrm{K}_{\text {ATP }}$ activator, diazoxide $(250 \mu \mathrm{mol} / \mathrm{l})$, or the SUR1specific activator [17], NN414 (5 $\mu \mathrm{mol} / \mathrm{l})$, rapidly hyperpolarised $V_{\mathrm{m}}$ and inhibited firing (Fig. 1f,g). Whole-cell voltage clamp (Fig. 1h,i) showed significant $\mathrm{K}^{+}$conductance, after washout of cell ATP, which was blocked by tolbutamide $(200 \mu \mathrm{mol} / \mathrm{l})$. These results indicate the presence of functional $\mathrm{K}_{\mathrm{ATP}}$ channels in GT1-7 cells, which are predominantly closed at euglycaemic $(2.5 \mathrm{mmol} / \mathrm{l})$ glucose.

Hypothalamic GT1-7 cells sense brain glucose concentrations In contrast with the lack of sensitivity over the physiological plasma glucose range (10-2.5 mmol/l) GT1-7 cells responded, reversibly, to a lower glucose concentration $(0.5 \mathrm{mmol} / \mathrm{l})$ by hyperpolarisation and cessation of firing, which occurred independently of the initial glucose concentration (Fig. 2a,b). This sensitivity was observed regardless of the glucose concentration in the culture medium. Thus, for GT1-7 cells maintained in $2.5 \mathrm{mmol} / 1$ glucose/DMEM, followed by $2.5 \mathrm{mmol} / \mathrm{l}$ glucose/saline, a reduction to $0.5 \mathrm{mmol} / \mathrm{l}$ glucose caused reversible hyperpolarisation $\left(2.5 \mathrm{mmol} / \mathrm{l}, V_{\mathrm{m}}=-46.8 \pm 2.2 \mathrm{mV} ; 0.5 \mathrm{mmol} / \mathrm{l}, V_{\mathrm{m}}=-61.3 \pm\right.$ $1.7 \mathrm{mV} ; p<0.001, n=6)$ indistinguishable from cells maintained in high-glucose DMEM (Fig. 2a). GT1-7 cells responded to glucose concentrations below $1 \mathrm{mmol} / \mathrm{l}$ (Fig. 2c), in agreement with the glucose sensitivity reported for GE hypothalamic neurons [10]. To address glucose sensitivity further, we used another mechanism that monitors cell energy availability [18], AMPK, and examined phosphorylation of AMPK (p-AMPK) and its downstream effector, ACC (p-ACC). In GT1-7 cells exposed to $0.1 \mathrm{mmol} / 1 \mathrm{glu}-$ cose for $30 \mathrm{~min}$ and challenged with increasing glucose concentrations, maximal sensitivity occurred below $1 \mathrm{mmol} / \mathrm{l}$ (Fig. 2d and ESM Fig. 2). We also assessed AMPK phosphorylation in relation to hypoglycaemic glucose concentrations $(2.5 \mathrm{mmol} / \mathrm{l}$ glucose starting point $)$, which also demonstrates optimal sensing at concentrations below $0.5 \mathrm{mmol} / 1$ (Fig. 2e). As GT1-7 cells hyperpolarised
Fig. 1 GT1-7 cells express functional $K_{i r} 6.2 /$ Sur 1 -containing $\mathrm{K}_{\text {ATP }}$ channels. (a) Bar graphs showing cycle threshold for real-time PCR amplification of Glut1,2,3 and 4,Hk1,2 and 3 and Gck mRNA from liver (grey bars), brain (hatched bars) and GT1-7 cells (black bars) ( $n=3$ for each). \# represents non-detectable. (b) Detection of brain/pancreastype GCK by PCR and immunoblot in GT1-7 cells. DNA was extracted from different tissues $(\mathrm{H}$, heart; $\mathrm{B}$, brain; $\mathrm{M}$, skeletal muscle; $\mathrm{F}$, fat; $\mathrm{L}$, liver; GT, GT1-7 cell line). La, DNA ladder. (c) Representative immunoblots for hexokinase (HK) and GCK in GT1-7 cells in comparison with mouse islets. (d) Bar graphs showing cycle threshold for real-time PCR amplification of Sur 1, Sur2a, Sur2b, $K_{i r} 6.1$ and $K_{i r} 6.2$ from GT1-7 cells ( $n=3$ for each). (e) Perforated patch recording from GT1-7 cell showing excitation by tolbutamide $(200 \mu \mathrm{mol} / \mathrm{l})$. The bar graph shows mean values for membrane potential in $2.5 \mathrm{mmol} / 1$ glucose, in the absence (Cont) and presence (Tolb) of tolbutamide $(n=6)$. (f,g) Perforated patch recordings from GT1-7 cells in $2.5 \mathrm{mmol} / 1$ glucose showing the reversible hyperpolarisation in response to diazoxide (DZX) (f) and NN414 (g). Bar graphs denote mean values of membrane potential in cells exposed to diazoxide $(n=4)$ and NN414 $(n=4)$. (h) Representative current-voltage relationships for voltage-clamped currents of GT1-7 cells. Mean currents were measured at various membrane potentials shortly after attaining whole-cell recording (i.e. before significant washout of ATP (control; squares) and $20 \mathrm{~min}$ later (after maximal washout of cellular ATP [0 ATP], circles) and with subsequent addition of tolbutamide (200 $\mu \mathrm{mol} / \mathrm{l}$, triangles). (i) Bar graph denotes mean conductance density $(n=4)$ obtained under the recording conditions described in (h). Values are means \pm SEM. ${ }^{*} p<0.05,{ }^{* *} p<0.01,{ }^{* * *} p<0.001$

to $0.5 \mathrm{mmol} / \mathrm{l}$ glucose (Fig. 2a), we were concerned that the immunoblot method was insufficiently sensitive. Consequently, direct AMPK activity assay showed that glucose reduction from 2.5 to $0.5 \mathrm{mmol} / \mathrm{l}$ significantly increased total AMPK activity after $15 \mathrm{~min}$ (Fig. 2f), when neuronal hyperpolarisation is maximal. In conclusion, the glucose concentrations that engendered the largest change in AMPK activity were between 1.0 and $0.1 \mathrm{mmol} / 1$, in good agreement with the electrical sensitivity to hypoglycaemia.

Glucose uptake and phosphorylation are required to maintain $K_{A T P}$ closure in GT1-7 cells Expression studies showed mRNA for Glut1, Glut3, Glut4 and hexokinase isoforms $H k 1, H k 2$ and $G c k$. Cytochalasin B $(20 \mu \mathrm{mol} / \mathrm{l})$, an inhibitor of facilitated glucose transporters [19], rapidly caused hyperpolarisation by opening $\mathrm{K}_{\mathrm{ATP}}$, as denoted by tolbutamide reversal (Fig. 3a). The non-specific hexokinase inhibitor, alloxan $(1 \mathrm{mmol} / \mathrm{l})$, or replacement of glucose with the anti-metabolite, 2-deoxyglucose, also hyperpolarised GT1-7 cells (Fig. 3b,c). These results indicate that glucose uptake and metabolism are required to maintain the resting potential of GT1-7 hypothalamic neurons.

As Gck mRNA and protein abundance were low, we used an alternative approach to demonstrate that GCK contributed to glucose-sensing behaviour in GT1-7 cells. The GCK activator, GKA50, prevents hyperpolarisation of pancreatic beta cells in response to hypoglycaemic challenge [9] and increases insulin secretion [20]. After hyperpolarisation by $0.5 \mathrm{mmol} / 1$ glucose, application of GKA50 ( $1 \mu \mathrm{mol} / \mathrm{l})$ caused depolarisation and increased firing (Fig. 3d), 

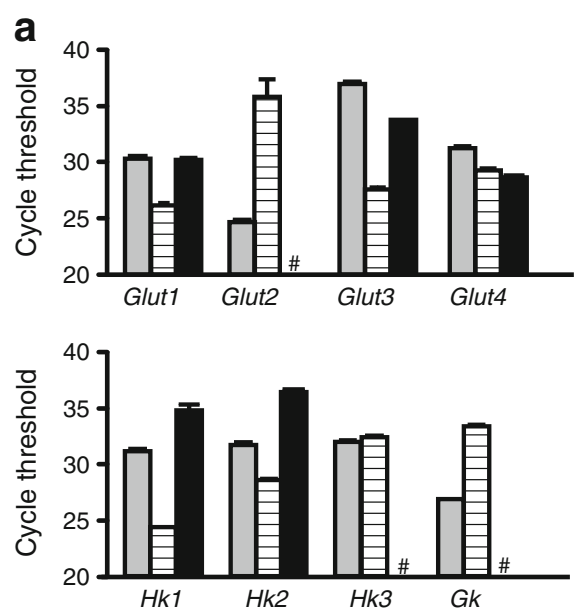

b

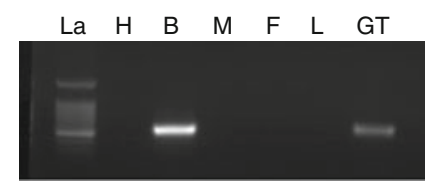

C

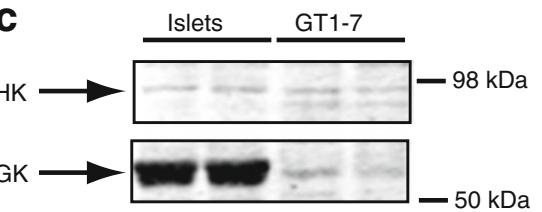

d

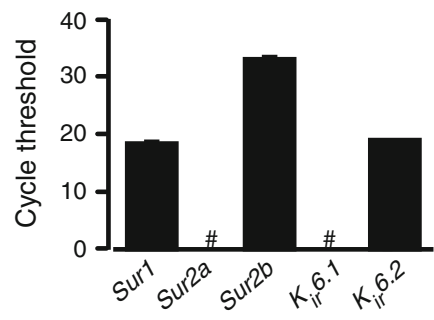

e
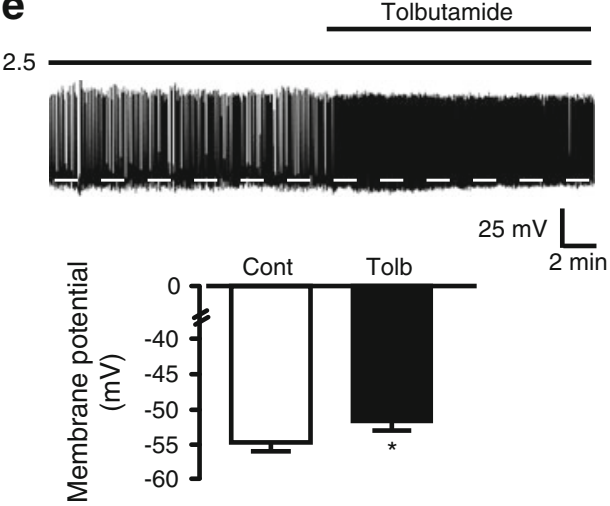

indicating increased glucose metabolic flux. Central neurons also metabolise lactate if their glucose supply is restricted [21], thus we determined whether GT1-7 cells could use this alternative energy source to maintain $V_{\mathrm{m}}$ under hypoglycaemic conditions. GT1-7 cells exposed to $0.1 \mathrm{mmol} / 1$ glucose f

2.5
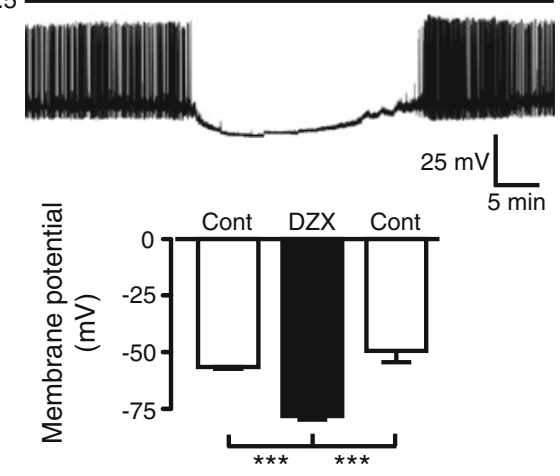

\begin{tabular}{ll}
$\mathbf{g}$ & $\mathrm{NN} 414$ \\
2.5 & \\
\hline
\end{tabular}
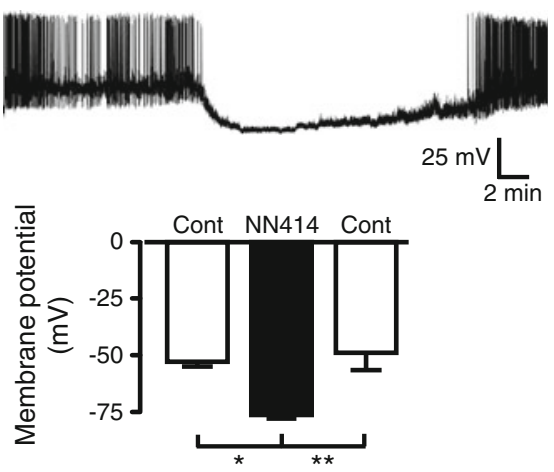

h
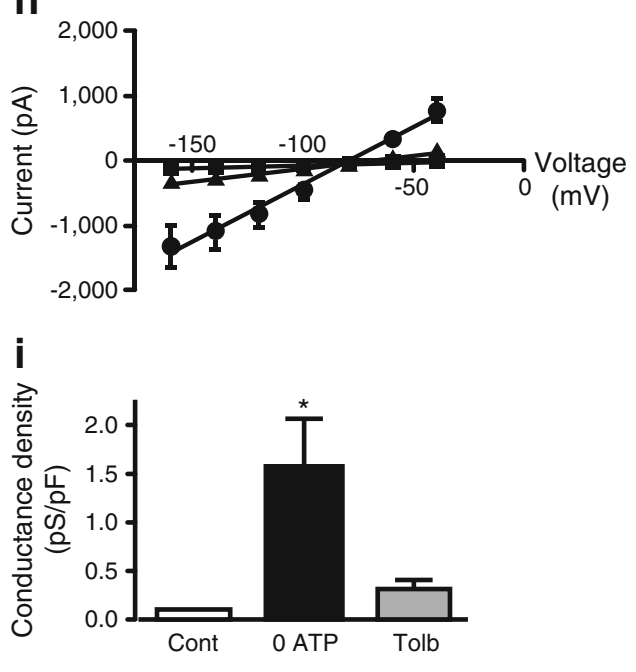

were depolarised when challenged with lactate at concentrations from 0.1 to $3.0 \mathrm{mmol} / 1$ (Fig. 3e). Although the mean changes in $V_{\mathrm{m}}$ induced by lactate only showed significance at 1.0 and $3.0 \mathrm{mmol} / \mathrm{l}$, we observed cells that clearly responded to $0.3 \mathrm{mmol} / \mathrm{l}$ lactate (Fig. $3 \mathrm{e}$ ). 
Fig. 2 GT1-7 cells are sensitive to brain glucose concentrations. (a,b) GT1-7 cells respond, reversibly, to a reduction in glucose from 10 (a) or 2.5 (b) to $0.5 \mathrm{mmol} / 1$ by hyperpolarisation and cessation of firing. Bar graphs show mean values for membrane potential of cells exposed to $10(\mathbf{a} ; n=7)$ or $2.5(\mathbf{b} ; n=5) \mathrm{mmol} / \mathrm{l}$ glucose, or $0.5 \mathrm{mmol} / 1$ glucose and diazoxide (DZX). (c) Mean membrane potential values for GT1-7 cells as a function of glucose concentration $(n=5-7)$. (d) Representative immunoblot showing the effect of increasing glucose concentration (0.1$20 \mathrm{mmol} / \mathrm{l}$ ) on $\mathrm{p}$-AMPK and p-ACC levels. (e) Representative immunoblot showing the effect of glucose $(0.1-$ $2.5 \mathrm{mmol} / \mathrm{l})$ on $\mathrm{p}$-AMPK and total AMPK levels. Bar graph shows relative mean level of pAMPK as a function of glucose concentration $(n=6)$. (f) AMPK activity (arbitrary units [AU]) measured in GT1-7 cells after their exposure to 2.5 and $0.5 \mathrm{mmol} / \mathrm{l}$ glucose for $15 \mathrm{~min}$ $(n=3)$. Values are means \pm SEM. ${ }^{*} p<0.05,{ }^{* *} p<0.01$, $* * * p<0.001$ a
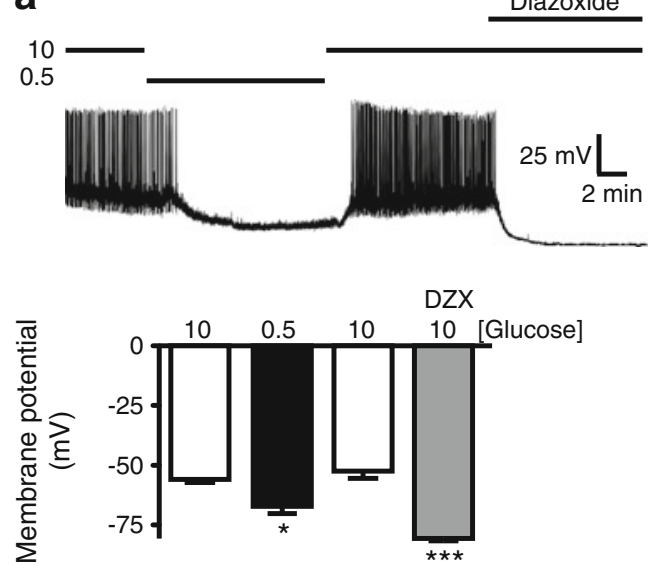

b

C

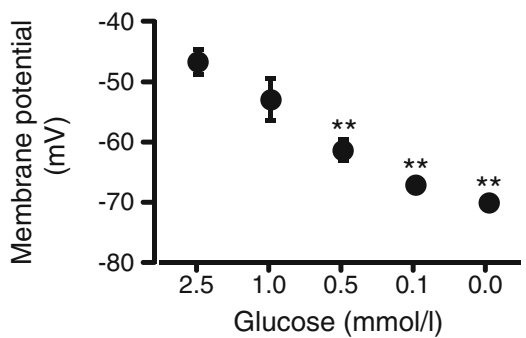

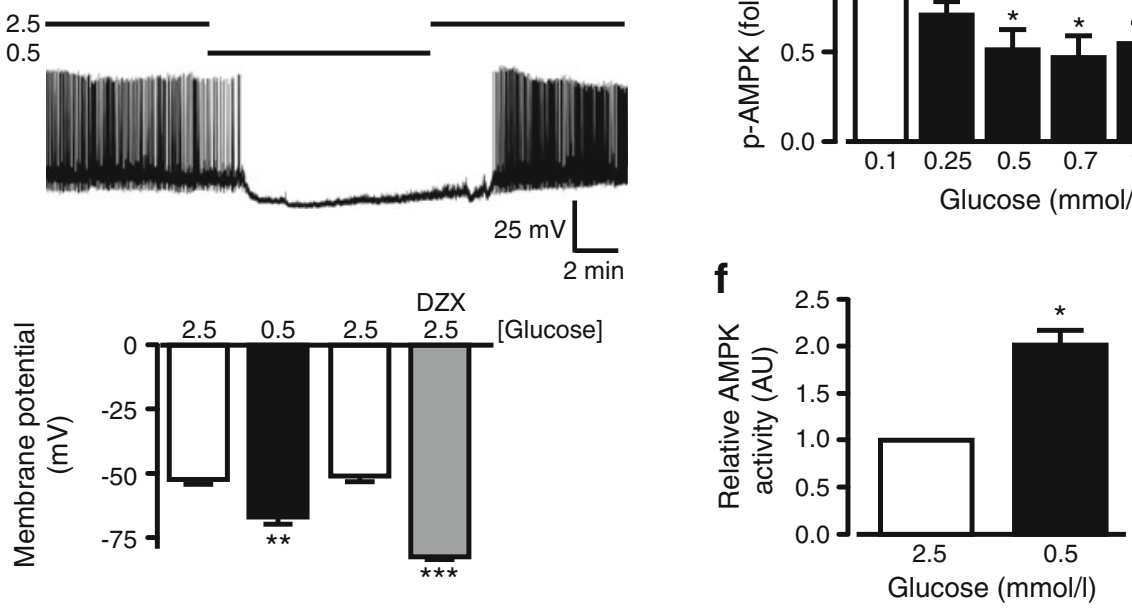

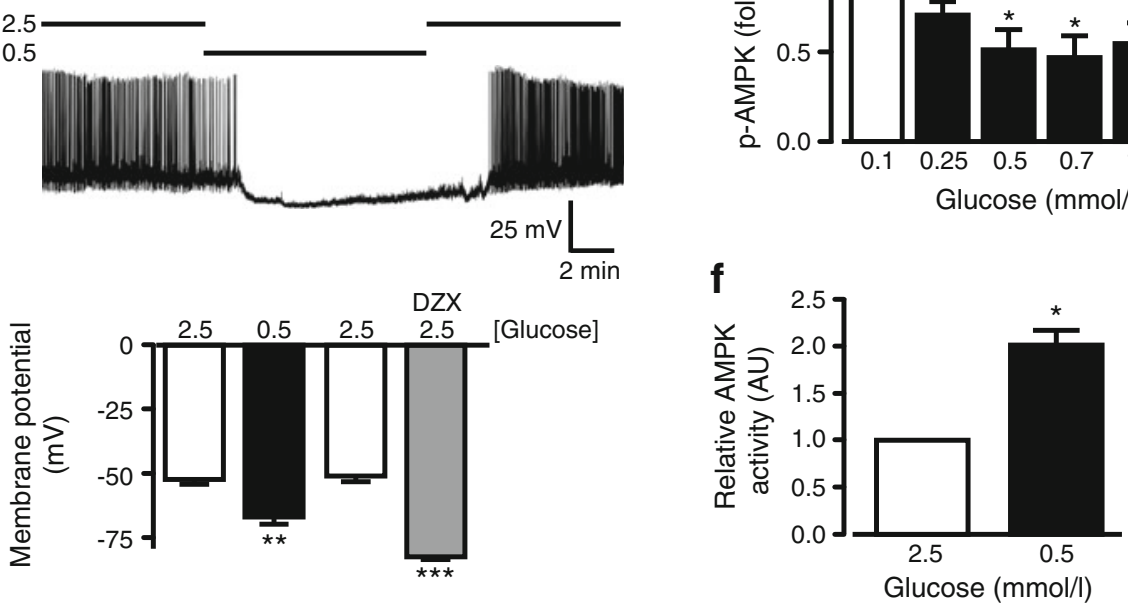

d

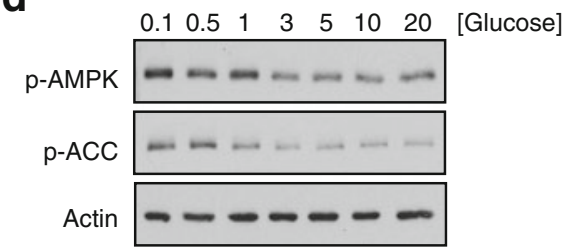

e
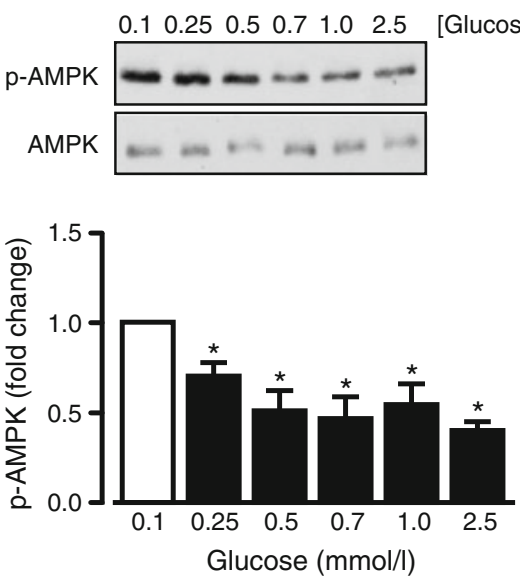

f

[Glucose]

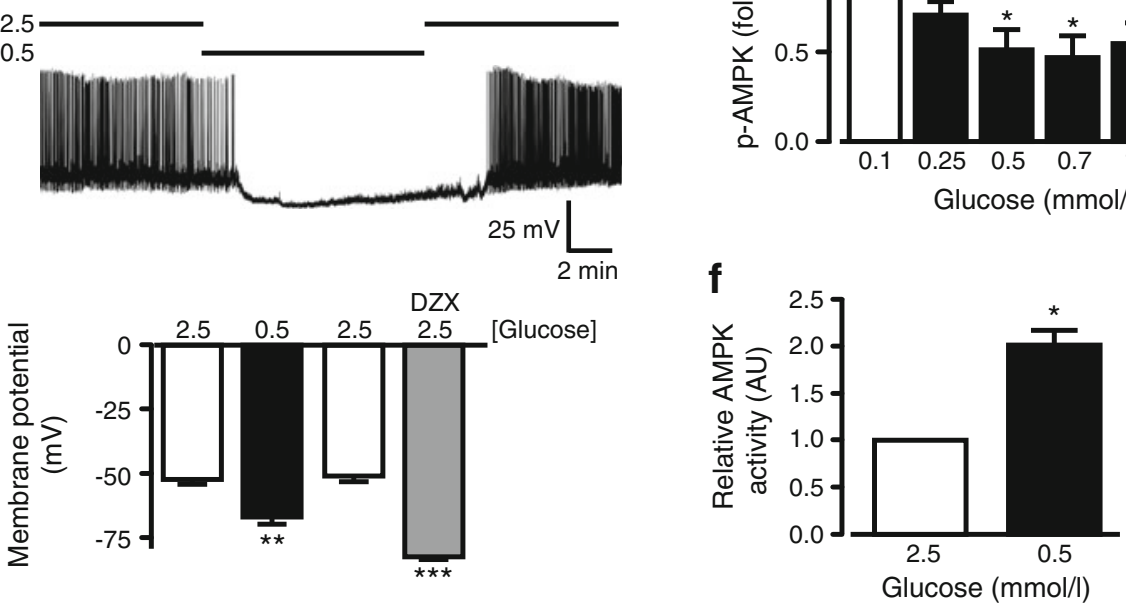

shAmpk $\alpha 2$ reduced AMPK $\alpha 2$, but not $\mathrm{AMPK} \alpha 1$, protein levels (Fig. 4a). Measurement of AMPK isoform specific activity showed that GT1-7 cells exhibited predominantly AMPK $\alpha 1\left(0.395 \pm 0.068 \mathrm{mU} \mathrm{min}^{-1} \mathrm{mg}^{-1} ; n=17\right)$ over AMPK $\alpha 2\left(0.0077 \pm 0.0017 \mathrm{mU} \mathrm{min}^{-1} \mathrm{mg}^{-1} ; n=17\right)$ activity, and that $100 \mu \mathrm{mol} / 1 \mathrm{H}_{2} \mathrm{O}_{2}$ significantly raised the activity of both isoforms (Fig. 4b,d). Although shAmpk 2 treatment of GT1-7 cells did not significantly alter basal AMPK $\alpha 2$ activity (Fig. 4b,c), it did prevent $\mathrm{H}_{2} \mathrm{O}_{2}$ activation of AMPK $\alpha 2$, but not AMPK $\alpha 1$, activity (Fig. 4b,d) and importantly prevented stimulation of AMPK $\alpha 2$ activity by hypoglycaemia (Fig. 4c). 

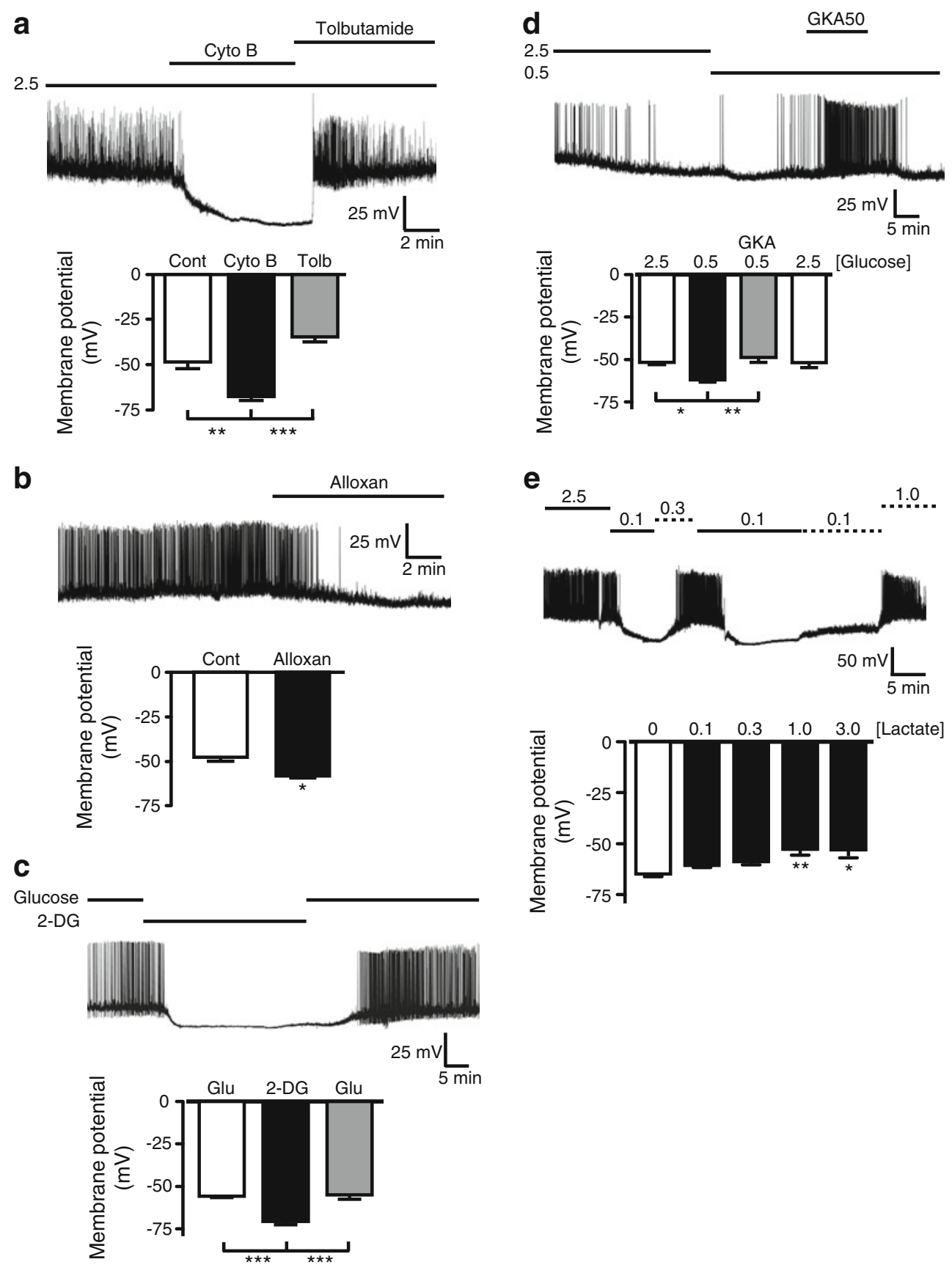

Fig. 3 Nutrient metabolism controls excitability of GT1-7 cells. (a) Perforated patch recording showing that cytochalasin B (Cyto B; $20 \mu \mathrm{mol} / \mathrm{l}$ ) hyperpolarises GT1-7 cells in $2.5 \mathrm{mmol} / 1$ glucose, an action reversed by tolbutamide $(200 \mu \mathrm{mol} / \mathrm{l})$. Bar graph shows mean values for membrane potential of cells exposed to $2.5 \mathrm{mmol} / \mathrm{l}$ glucose (Cont), cytochalasin B and tolbutamide (Tolb; $n=5)$. (b) Alloxan $(1 \mathrm{mmol} / \mathrm{l})$ hyperpolarises GT1-7 cells. Bar graph shows mean membrane potentials under control conditions $(2.5 \mathrm{mmol} / \mathrm{l}$ glucose $)$ and in alloxan $(n=4)$. (c) Replacement of $2.5 \mathrm{mmol} / 1$ glucose with $2.5 \mathrm{mmol} / 1$ 2-deoxyglucose (2-DG) reversibly hyperpolarises GT1-7 cells. Bar graph denotes mean membrane potential of cells exposed to glucose and 2-deoxyglucose $(n=$

shCont-treated GT1-7 cells displayed electrical activity in $2.5 \mathrm{mmol} / 1$ glucose and responded to $0.5 \mathrm{mmol} / 1$ glucose by
4). (d) Application of the GCK activator, GKA50 (1 $1 \mu \mathrm{mol} / \mathrm{l})$ reverses the hyperpolarisation and inhibition of firing caused by $0.5 \mathrm{mmol} / \mathrm{l}$ glucose. Bar graph shows mean membrane potential of cells exposed to $2.5 \mathrm{mmol} / 1$ glucose and $0.5 \mathrm{mmol} / 1$ glucose with or without GKA50 $(n=6)$. (e) Lactate compensates for low glucose in maintenance of GT1-7 cell membrane potential and excitability. Solid and broken lines denote glucose and lactate concentrations, respectively, with individual concentrations given above the trace. Bar graph shows mean membrane potential of cells in $0.1 \mathrm{mmol} / 1$ glucose (white bar) or lactate $\left(0.1-3.0 \mathrm{mmol} / \mathrm{l} ; n=5-9\right.$; black bars). Values are means \pm SEM. ${ }^{*} p<0.05$, $* * p<0.01, * * * p<0.001$

hyperpolarisation and cessation of firing (Fig. 4e) in a manner indistinguishable from untreated cells. In contrast, 
Fig. 4 AMPK $\alpha 2$ activity modifies GT1-7 sensitivity to hypoglycaemia. (a) Lentiviral delivery of shRNA targeting AMPK $\alpha 2$ reduces AMPK $\alpha 2$, but not AMPK $\alpha 1$, protein levels. Cells treated with control lentiviral vector (shCont) are unaffected. (b-d) sh $A m p k \alpha 2$ prevents $\mathrm{H}_{2} \mathrm{O}_{2}$ - (b) and lowglucose- $(0.5 \mathrm{mmol} / \mathrm{l}$; c) induced increase in AMPK $\alpha 2$ activity (arbitrary units [AU]), but has no effect (d) on $\mathrm{H}_{2} \mathrm{O}_{2}$-induced increase in AMPK $\alpha 1$ activity, $(n=4-7)$. White bars denote vehicle-treated cells and black bars $\mathrm{H}_{2} \mathrm{O}_{2}$-treated cells in (b) and (d), whereas in (c) white bars denote cells exposed to $2.5 \mathrm{mmol} / 1$ glucose and black bars cells exposed to $0.5 \mathrm{mmol} / 1$ glucose. (e) Representative recording showing the electrical response of GT1-7 cells infected with shCont to a reduction in glucose from 2.5 to $0.5 \mathrm{mmol} / 1$ and to application of NN414. Bar graph shows mean values for membrane potentials under the conditions described $(n=3-6)$. (f,g) GT1-7 cells infected with shAMPK $\alpha 2$ show no electrical response to $0.5 \mathrm{mmol} / \mathrm{l}$ glucose (f), but do respond to a more extreme hypoglycaemic (0.25 mmol/1 glucose) stimulus (g). Bar graphs show mean values of membrane potential for shAMPK $\alpha 2$-treated GT1-7 cells challenged with $0.5 \mathrm{mmol} / 1(\mathbf{f} ; n=6)$ and $0.25 \mathrm{mmol} / \mathrm{l}(\mathbf{g} ; n=5)$ glucose. (h) Bar graph denotes mean conductance density under voltage clamp, in control (immediately after formation of stable clamp) and after a washout of ATP from the cell (20 min) for GT1-7 cells infected with shCont and shAMPK $\alpha 2$ lentivirus $(n=6-8)$.

Values are means \pm SEM.

${ }^{*} p<0.05,{ }^{*} p<0.01$,

$* * * p<0.001$ a
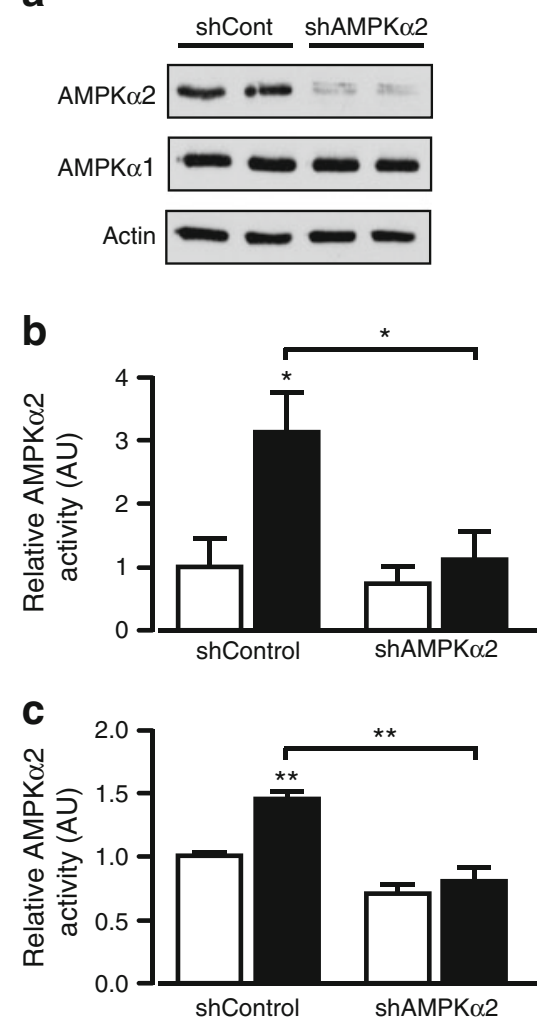

d

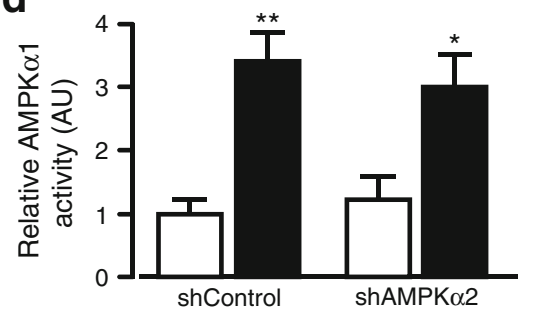

e

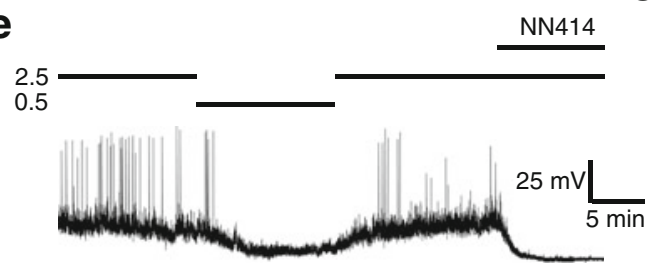

NN414

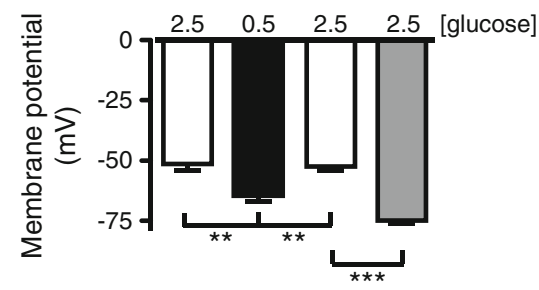

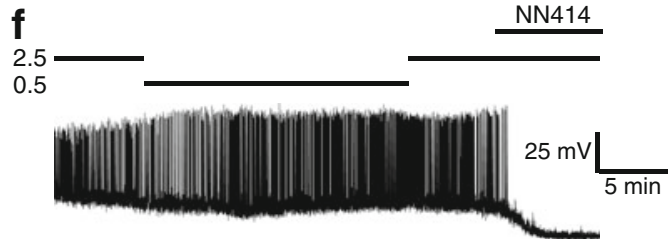
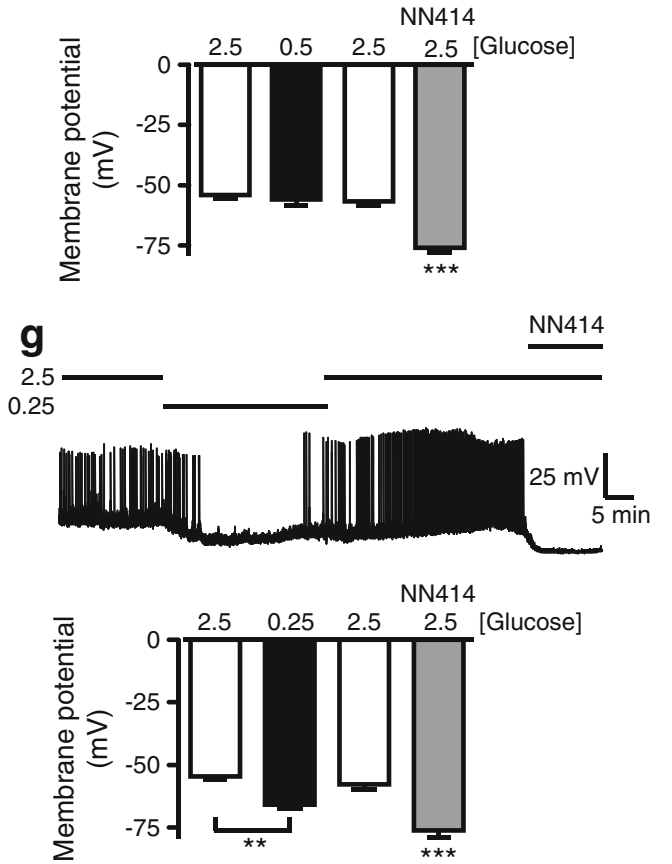

h

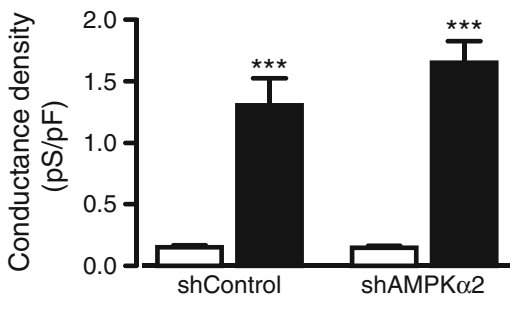

sh Ampk $\alpha 2$-treated cells were less responsive to hypoglycaemic challenge, with $0.5 \mathrm{mmol} / \mathrm{l}$ glucose having no effect on $V_{\mathrm{m}}$ or firing rate (Fig. 4f). However, these cells were responsive to more severe hypoglycaemic challenge, with
$0.25 \mathrm{mmol} / \mathrm{l}$ (Fig. $4 \mathrm{~g})$ and $0.1 \mathrm{mmol} / \mathrm{l}\left(\Delta \mathrm{V}_{\text {Cont }}=-9.7 \pm\right.$ $\left.2.1 \mathrm{mV} ; \Delta \mathrm{V}_{\text {shAMPK } \alpha 2}=-13.5 \pm 4.3 \mathrm{mV} ; n=4 ; p>0.1\right)$ glucose exposure causing hyperpolarisation. Thus treatment of GT1-7 cells with shAmpka2 shifts the threshold for 
detection electrically to a more severe hypoglycaemia stimulus. This shift in glucose-sensing capability was not associated with any change in maximal $\mathrm{K}_{\mathrm{ATP}}$ conductance of GT1-7 cells (Fig. 4h). As responsiveness to NN414 was also unaltered (compare Fig. 4e,f and Fig. 1g), it is likely that no change in $\mathrm{K}_{\text {ATP }}$ availability is associated with modification of glucose sensing. ShAmpka1-treated GT1-7 cells exhibited reduced AMPK $\alpha 1$ protein levels (Fig. 5a) and depressed $\mathrm{H}_{2} \mathrm{O}_{2}$-stimulated AMPK $\alpha 1$ activity (Fig. 5b), which was not associated with loss of AMPK $\alpha 2$ protein levels or activity. Furthermore, stimulation with $\mathrm{H}_{2} \mathrm{O}_{2}$ increased AMPK $\alpha 2$ activity, identical with the control (Fig. 5d). Although shAmpka1 treatment of GT1-7 cells ablated stimulation of AMPK $\alpha 1$ activity by $0.5 \mathrm{mmol} / 1$ glucose (Fig. 5c), robust and reproducible hyperpolarising responses to $0.5 \mathrm{mmol} / 1$ glucose were observed (Fig. $5 \mathrm{e}$ ), indicating that $\mathrm{AMPK} \alpha 2$, rather than AMPK $\alpha 1$, activity is required for cells to respond electrically to hypoglycaemia.

UCP2 may also contribute to glucose sensing in GT1-7 cells Previous work suggests a role for UCP2 in the glucose-sensing behaviour of beta cells and hypothalamic neurons [22-24], with $\mathrm{K}_{\text {ATP }}$ activation and hyperpolarisation induced by low glucose in beta cells and proopiomelanocortin (POMC) neurons prevented by pharmacological inhibition of UCP2 with genipin $[9,24]$. In agreement, we found that genipin $(100 \mu \mathrm{mol} / \mathrm{l})$ prevented GT1-7 cells from responding electrically to hypoglycaemia (Fig. 6a). Furthermore, treatment of GT1-7 cells with shAmpk 2 significantly reduced Ucp 2 mRNA levels, in comparison with shConttreated cells (Fig. 6b), suggesting a close link between AMPK $\alpha 2$ activity and UCP2 content.

\section{Discussion}

GT1-7 cells, which make and secrete gonadotrophinreleasing hormone $(\mathrm{GnRH})$ exhibit intrinsic glucosesensing properties after reduction of extracellular glucose from the euglycaemic levels $(2.5 \mathrm{mmol} / \mathrm{l})$ normally associated with brain. As reported here for GT1-7 cells, mouse GnRH neurons express mRNA for $G c k$ and the $\mathrm{K}_{\text {ATP }}$ subunits $K_{i r} 6.2$ and Surl, and respond to lowered glucose by $\mathrm{K}_{\mathrm{ATP}}$-dependent hyperpolarisation [25]. Furthermore, $K_{i r} 6.2$ and Sur 1 mRNAs have been demonstrated in hypothalamic GE neurons using single-cell RT-PCR [7, 26]. However, the presence of these transcripts did not completely correlate with GE neuron phenotype, and expression of the combination, $K_{i r} 6.1$ and Surl, has also been reported in hypothalamic GE neurons [27]. Our findings that GT1-7 cells express
Fig. 5 Hypoglycaemic responses are insensitive to reduction in AMPK $\alpha 1$. (a) Lentiviral delivery of shRNA targeting AMPK $\alpha 1$ reduces AMPK $\alpha 1$, but not AMPK $\alpha 2$, protein levels. Cells treated with control lentiviral vector (shCont) are unaffected. (b-d) shAMPK $\alpha 1$ reduces $\mathrm{H}_{2} \mathrm{O}_{2}$ (b) and $0.5 \mathrm{mmol} / 1$ glucose (c)induced increase in AMPK $\alpha 1$ activity (arbitrary units [AU]), but has no effect (d) on $\mathrm{H}_{2} \mathrm{O}_{2}$ induced increase in AMPK $\alpha 2$ activity $(n=4-12)$. White bars denote vehicle-treated cells and black bars $\mathrm{H}_{2} \mathrm{O}_{2}$-treated cells in (b) and (d), whereas in (c) white bars denote cells exposed to $2.5 \mathrm{mmol} / 1$ glucose and black bars cells exposed to $0.5 \mathrm{mmol} / 1$ glucose. (e) GT1-7 cells infected with shAMPK $\alpha 1$ show a normal electrical response to $0.5 \mathrm{mmol} / \mathrm{l}$ glucose. Bar graph shows mean values of membrane potential for shAMPK $\alpha 1$-treated GT1-7 cells challenged with $0.5 \mathrm{mmol} / 1$ glucose and NN414 $(n=4-6)$. Values are means \pm SEM. ${ }^{*} p<0.05$, $* * p<0.01, * * * p<0.001$ a

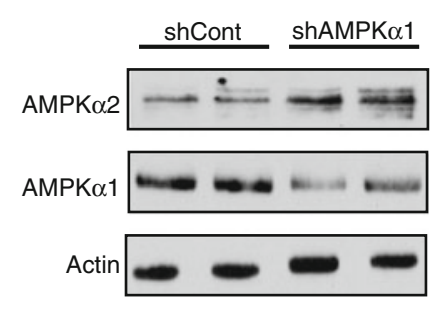

b
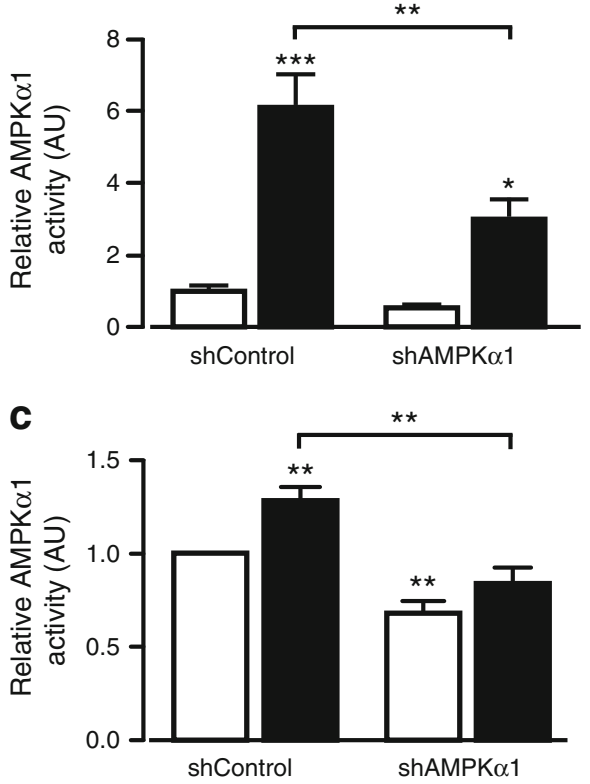

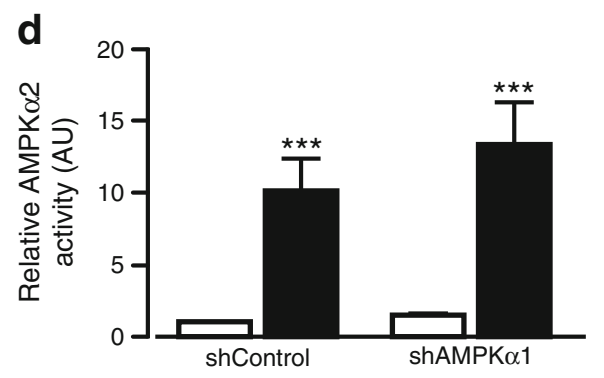

e

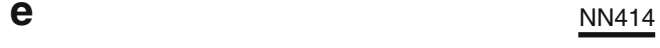

2.5
0.5
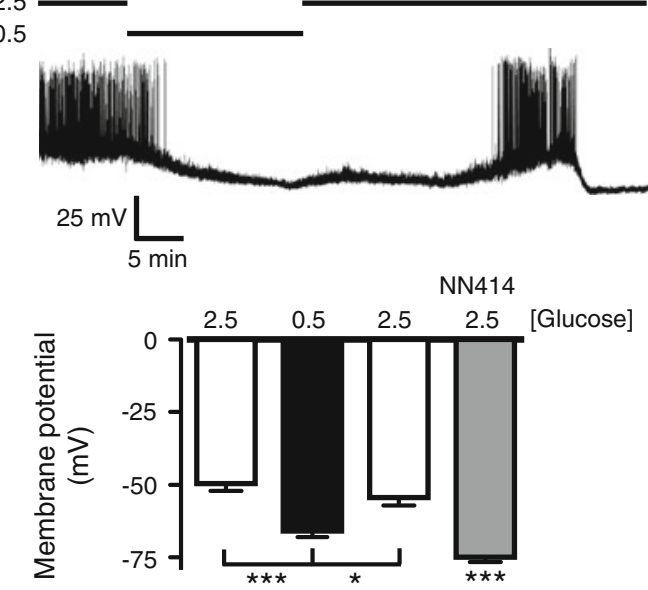


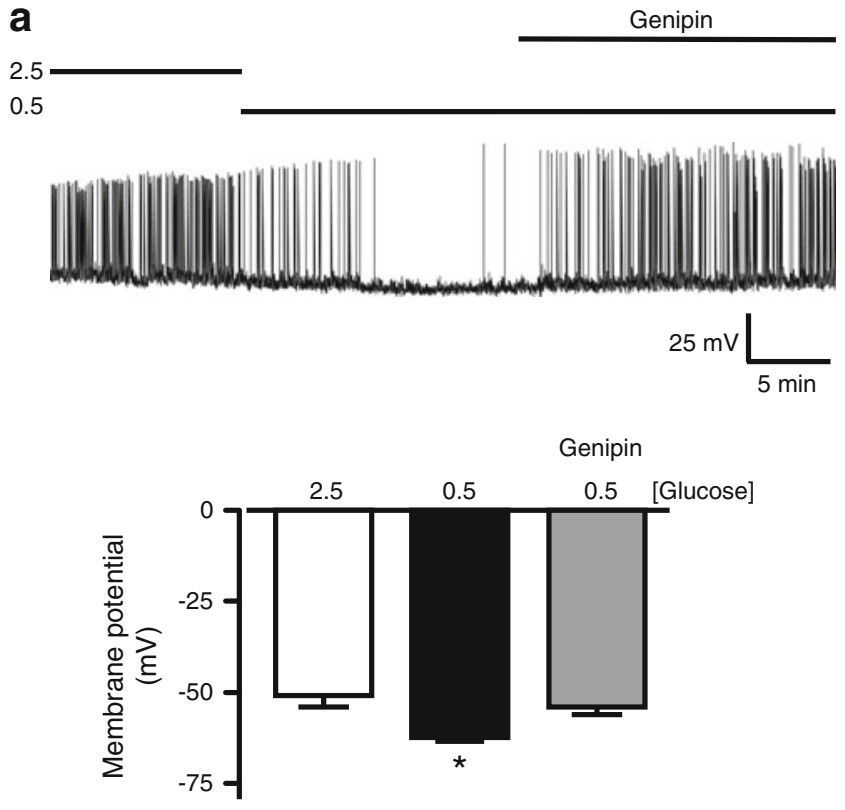

b

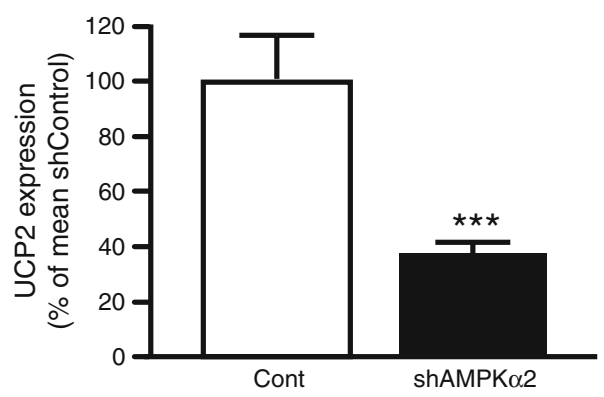

Fig. 6 Reduction in UCP2 may link AMPK and glucose sensing in GT1-7 cells. (a) Representative recording showing the effects of genipin $(100 \mu \mathrm{mol} / \mathrm{l})$ on uninfected GT1-7 cells, in the presence of $0.5 \mathrm{mmol} / 1$ glucose. Bar graph shows mean values of membrane potential for cells in $2.5 \mathrm{mmol} / 1$ glucose and $0.5 \mathrm{mmol} / 1$ glucose with or without genipin $(n=5)$. (b) Treatment of cells with shAMPK $\alpha 2$ reduces UCP2 mRNA levels $(n=15-17)$. Values are means \pm SEM. ${ }^{*} p<0.05,{ }^{* * *} p<0.001$

$K_{i r} 6.2$ and Surl, but not $K_{i r} 6.1$, mRNA support the notion that the beta cell $\mathrm{K}_{\text {ATP }}$ subunit combination underlies GE neuron effector responses to hypoglycaemia. Demonstrable levels of $\mathrm{K}_{\mathrm{ir}} 6.2$ protein and $\mathrm{K}_{\mathrm{ATP}}$ activation by diazoxide and NN414 and inhibition by tolbutamide also support this subunit permutation. In keeping with the proposed role for GCK as 'gatekeeper' of neuronal glucose sensing [28, 29], GCK inhibition by alloxan or activation by GKA50 [20] mimicked or reversed the effects of hypoglycaemic challenge. These results indicate major roles for $\mathrm{K}_{\mathrm{ATP}}$ and GCK in mediating glucose sensing in GT1-7 cells as described for pancreatic beta cells $[30,31]$. In rodent beta cells, GLUT2 mediates glucose entry under physiological glucose concentrations [32]. However, GT1-7 cells only expressed Glut1, Glut3 and Glut4 transcripts. GLUT2 is mainly located in astrocytes, with GLUT3 being the primary neuronal transporter, although GLUT1 and GLUT4 have been reported in neurons [33]. Indeed, glial GLUT2 may be required for normal glucagon secretion in response to hypoglycaemia [34]. GLUT1 and GLUT3 have low $K_{\mathrm{m}}$ values ( $\sim 1 \mathrm{mmol} / \mathrm{l}[33])$ consistent with the glucose sensitivity of hypothalamic GE neurons $[10,35,36]$ and GT1-7 cells. GLUT4 has a $K_{\mathrm{m}}$ that encompasses the physiological range of brain glucose and could allow insulin-mediated modulation of glucose uptake, as described for hypothalamic GE neurons [37].

The lack of responsiveness to glucose above $2.5 \mathrm{mmol} / \mathrm{l}$ and the small effect of tolbutamide in $2.5 \mathrm{mmol} / 1$ glucose indicate that GT1-7 $\mathrm{K}_{\text {АTP }}$ channels are mostly closed in euglycaemic and hyperglycaemic conditions. This has previously been reported for GE neurons [38], and contrasts with larger beta cell responses to tolbutamide under euglycaemic conditions, indicating the greater influence of $\mathrm{K}_{\mathrm{ATP}}$ on the resting $V_{\mathrm{m}}$ of beta cells. Indeed, the baseline resting $V_{\mathrm{m}}$ of GT1-7 cells of $\sim-50 \mathrm{mV}$ is similar to that reported previously for hypothalamic GE neurons [10, 26, 27, 36, 37, 39]. In contrast, reducing the glucose concentration to $1.0 \mathrm{mmol} / \mathrm{l}$ or below caused reversible $\mathrm{K}_{\mathrm{ATP}}$-dependent hyperpolarisation and reduction, or loss, of firing of GT1-7 cells. The sensitivity of GT1-7 $V_{\mathrm{m}}$ to agents that suppress glucose uptake and metabolism indicates the requirement, as observed for beta cells, for glucose entry and metabolism to maintain $\mathrm{K}_{\mathrm{ATP}}$ in the predominantly closed conformation. Glial cells, such as astrocytes, provide neurons with energy substrates [3] such as lactate, which, in conjunction with monocarboxylate transporters, cause closure of $\mathrm{K}_{\mathrm{ATP}}$ in GE neurons [39]. Thus astrocyte lactate production may act as an energy fuel reserve for neurons, maintaining their electrical activity during hypoglycaemia [1]. Although GT1-7 cells are intrinsic glucose sensors, the presence of Slcl6a7 mRNA and the ability of exogenous lactate to depolarise and excite these cells under conditions of glucose deprivation indicate that lactate conversion into pyruvate in neurons could maintain their $V_{\mathrm{m}}$ and excitability during hypoglycaemic episodes. Indeed, the similar concentration response of lactate and glucose on $V_{\mathrm{m}}$ indicates that lactate is a more effective energy substrate, on an energy basis, at closing $\mathrm{K}_{\text {ATP }}$ channels. Consequently, GT1-7 cells behave as direct glucose and lactate sensors.

AMPK is an important nutrient sensor and effector mechanism in cells, allowing detection of lowered cell energy status with coupling to intrinsic cell mechanisms designed to restore energy balance. Changes in AMPK activity have been implicated in counter-regulatory hormone responses to hypoglycaemia $[11,12]$, and a role for AMPK has been proposed for hypoglycaemia-dependent depolarisation of hypothalamic GI neurons [40,41]. In addition, deletion of the AMPK $\alpha 2$ catalytic subunit in beta cells [9] and identified hypothalamic neurons [10] prevents hypoglycaemic challenge from $\mathrm{K}_{\text {АTP }}$ activation 


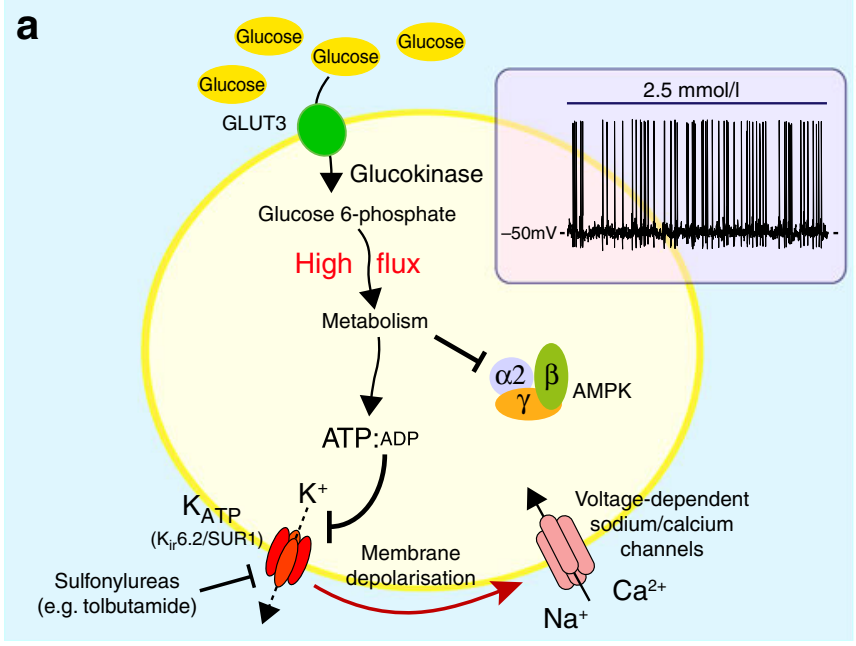

Fig. 7 Model of GT1-7 cell illustrating the molecular components indicative of a GE neuron. In order to correlate neuronal firing with glucose concentration, the cell must have a glucose-sensing and measuring system. This is denoted by the presence of the glucose-transport protein GLUT3 and glucokinase. (a) Glucose uptake and glucokinase activity are sufficient under euglycaemic conditions $(2.5 \mathrm{mmol} / \mathrm{l})$ to produce sufficient metabolic flux to maintain a high ATP/ADP ratio. This keeps AMPK $\alpha 2$ activity low (basal) and $\mathrm{K}_{\text {ATP }}$ channels predominantly in the closed conformation, thus maintaining a relatively

and hyperpolarisation. Hypoglycaemia increases AMPK activity in GT1-7 cells with a glucose concentration-dependence that mirrors the electrical change. By using shRNA targeted to AMPK $\alpha$ subunits, we decreased protein levels of the targeted subunit sufficiently to reduce its maximal activation by $\mathrm{H}_{2} \mathrm{O}_{2}$ and prevent AMPK $\alpha$ activation by $0.5 \mathrm{mmol} / \mathrm{l}$ glucose. This demonstrated that reducing $\mathrm{AMPK} \alpha 2$, but not AMPK $\alpha 1$, activity prevented the hyperpolarising response to $0.5 \mathrm{mmol} / 1$ glucose, but not to stronger stimuli, indicating a shift in the glucose-sensing threshold away from the physiologically relevant range. This result puts AMPK $\alpha 2$ activity (which is only $\sim 2 \%$ of total AMPK activity in GT1-7 cells) directly in the glucosesensing pathway of GE neurons.

Therefore, what links AMPK $\alpha 2$ activity with GE neuron metabolism and $\mathrm{K}_{\mathrm{ATP}}$ channels? It is generally considered that modulation of beta cell $\mathrm{K}_{\mathrm{ATP}}$ activity by glucose metabolism is driven by changes in the ATP/ ADP ratio. Glucose sensing is negatively regulated by raised UCP2 activity, which is argued to diminish the yield of ATP from glucose, causing beta cell dysfunction [23, 42]. Ucp2 is highly expressed in the hypothalamus [43], and recent studies suggest that UCP2 negatively regulates glucose sensing in hypothalamic neurons $[24,44]$. Increased UCP2 decreases mitochondrial $V_{\mathrm{m}}$ and respiration, via uncoupling, and is expected to reduce the ATP/ADP ratio, thus causing $\mathrm{K}_{\text {ATP }}$ opening. This scenario is supported by the observation that genipin closes

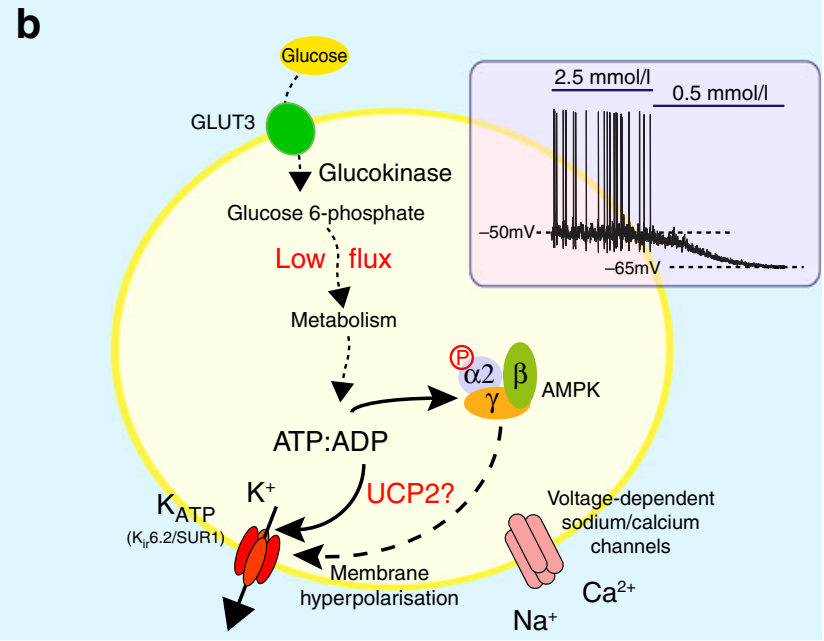

depolarised membrane potential and regular firing (as illustrated by the inset figure). (b) If the cell is now exposed to a hypoglycaemic environment (e.g. $0.5 \mathrm{mmol} / 1$ glucose), there is reduced glucose metabolic flux, which results in a reduced ATP/ADP ratio (thought to be due to increased ADP, as phosphotransfer reactions maintain ATP levels). This rise in sub-plasma membrane ADP, in conjunction with increased AMPK $\alpha 2$ activity (possibly associated with increased UCP2 activity) causes increased $\mathrm{K}_{\mathrm{ATP}}$ channel activity, resulting in cell hyperpolarisation and cessation of firing

$\mathrm{K}_{\mathrm{ATP}}$ and depolarises beta cells and POMC neurons, and this requires the presence of UCP2 [30, 32]. Under hypoglycaemic conditions, genipin closes $\mathrm{K}_{\mathrm{ATP}}$ and depolarises GT1-7 cells, suggesting a UCP2-mediated change in glucose metabolism in these cells. However, we have been unable to detect an alteration in bulk ATP/ADP during hypoglycaemia in GT1-7 cells (ESM Fig. 3), consistent with a previous study [39] of GE neurons. It is plausible that localised, sub-membrane alterations of ATP/ ADP are responsible for generating the signals that control $\mathrm{K}_{\mathrm{ATP}}$ gating under hypoglycaemic conditions and our measures are simply insufficiently sensitive. Nevertheless, reducing AMPK $\alpha 2$ in GT1-7 cells significantly decreased Ucp 2 mRNA levels, an outcome also reported in islets from mice lacking $\mathrm{AMPK} \alpha 2$ in beta cells [9]. Thus AMPK $\alpha 2$ activity may, in an as yet undefined way, be positively linked to $U c p 2$ transcription in GE neurons and pancreatic beta cells. Interestingly, activation of AMPK increases Ucp 2 expression in beta cells [45-47].

Our findings demonstrate that the GT1-7 cell line is an excellent model with which to probe hypothalamic glucosesensing mechanisms. GT1-7 cells replicate the critical features of hypothalamic GE neurons, with functional expression of the molecular components essential for metabolic sensing and transduction to an electrical signal, as exemplified by beta cells. Decreasing AMPK $\alpha 2$ activity in GT1-7 cells diminished electrical sensitivity to a moderate hypoglycaemic 
stimulus, an action that may require reduced UCP2, although we have no definitive data to prove this at present. We hypothesise that AMPK $\alpha 2$ acts as a sensor of fluctuations in glucose concentration by connecting glucose metabolism, through modulation of UCP2, with changes in local nucleotide levels (e.g. ADP), $\mathrm{K}_{\text {ATP }}$ channel activity and electrical excitability (Fig. 7). Furthermore, it is possible that hormones such as leptin and/or amylin could, by modifying AMPK activity [48], alter this intrinsic glucose-sensing behaviour. Functional deficits of any one of the classical components of glucose-sensing cells (e.g. $\mathrm{K}_{\mathrm{ATP}}$, GLUT2 and GCK) engender dysfunctional output, as exemplified for pancreatic beta cells and type 2 diabetes [30, 49, 50]. Consequently any loss of function involving AMPK $\alpha 2-\mathrm{UCP} 2$ in beta cells or GE neurons may have a similar outcome. Therefore, in the context of hypothalamic glucose sensing, it will be interesting to determine whether defective glucose counter-regulation after recurrent bouts of hypoglycaemia is associated with alterations in the putative hypothalamic AMPK $\alpha 2-\mathrm{UCP} 2$ pathway.

\section{Acknowledgements We thank Novo Nordisk for providing NN414.}

Funding This study was funded by: grants from the Wellcome Trust (grant numbers 068692 and 086989) and Diabetes UK (grant number RD08/0003681) to M.L.J. Ashford; a Juvenile Diabetes Research Foundation (JDRF) Postdoctoral Fellowship to C. Beall (grant number 3-576-2010); grants from JDRF and European Foundation for the study of Diabetes to R.J. McCrimmon, and from the British Heart Foundation to A. Jovanović.

Duality of interest The authors declare that there is no duality of interest associated with this manuscript. Novo Nordisk had no involvement in this study.

Contribution statement $\mathrm{CB}$ and DLH acquired and analysed data, contributed to experimental design, interpretation of data and to revision of the manuscript, JG, LL, KW, MPS, SD, FBA, EH, QD and AJ acquired and analysed data and revised the manuscript, RJM contributed to conception of study, experimental design, interpretation of data and revised the manuscript; MLJA contributed to conception of study, experimental design, interpretation of data, and drafted, revised and edited the manuscript. All authors approved the final version.

Open Access This article is distributed under the terms of the Creative Commons Attribution Noncommercial License which permits any noncommercial use, distribution, and reproduction in any medium, provided the original author(s) and the source are credited.

\section{References}

1. McCrimmon RJ, Sherwin RS (2010) Hypoglycemia in type 1 diabetes. Diabetes 59:2333-2339
2. Dunn-Meynell AA, Sanders NM, Compton D et al (2009) Relationship among brain and blood glucose levels and spontaneous and glucoprivic feeding. J Neurosci 29:7015-7022

3. Levin BE, Magnan C, Dunn-Meynell A, Le Foll C (2011) Metabolic sensing and the brain: who, what, where and how? Endocrinology 152:2552-2557

4. Karnani M, Burdakov D (2011) Multiple hypothalamic circuits sense and regulate glucose levels. Am J Physiol Regul Integr Comp Physiol 300:R47-R55

5. Tarasov A, Dusonchet J, Ashcroft FM (2004) Metabolic regulation of the pancreatic beta-cell ATP-sensitive $\mathrm{K}^{+}$channel: a pas de deux. Diabetes 53:S113-S122

6. Burdakov D, Luckman SM, Verkhratsky A (2005) Glucose-sensing neurons of the hypothalamus. Phil Trans R Soc B 360:2227-2235

7. Kang L, Routh VH, Kuzhikandathil EV, Gaspers LD, Levin BE (2004) Physiological and molecular characteristics of rat hypothalamic ventromedial nucleus glucosensing neurons. Diabetes 53:549-559

8. Gonzàlez JA, Reimann F, Burdakov D (2009) Dissociation between sensing and metabolism of glucose in sugar sensing neurones. J Physiol 585:41-48

9. Beall C, Piipari K, Al-Qassab H et al (2010) Loss of AMPactivated protein kinase alpha2 subunit in mouse beta-cells impairs glucose-stimulated insulin secretion and inhibits their sensitivity to hypoglycaemia. Biochem J 429:323-333

10. Claret M, Smith MA, Batterham RL et al (2007) AMPK is essential for energy homeostasis regulation and glucose sensing by POMC and AgRP neurons. J Clin Invest 117:2325-2336

11. McCrimmon RJ, Shaw M, Fan X et al (2008) Key role for AMPactivated protein kinase in the ventromedial hypothalamus in regulating counterregulatory hormone responses to acute hypoglycemia. Diabetes 57:444-450

12. McCrimmon RJ, Fan X, Cheng H et al (2006) Activation of AMPactivated protein kinase within the ventromedial hypothalamus amplifies counterregulatory hormone responses in rats with defective counterregulation. Diabetes 55:1755-1760

13. Mellon PL, Windle JJ, Goldsmith PC, Padula CA, Roberts JL, Weiner RI (1990) Immortalization of hypothalamic GnRH neurons by genetically targeted tumorigenesis. Neuron 5:1-10

14. Mirshamsi S, Laidlaw HA, Ning K et al (2004) Leptin and insulin stimulation of signalling pathways in arcuate nucleus neurones: PI 3-kinase dependent actin reorganization and $\mathrm{K}_{\mathrm{ATP}}$ channel activation. BMC Neurosci 5:54

15. Hawley SA, Ross FA, Chevtzoff C et al (2010) Use of cells expressing gamma subunit variants to identify diverse mechanisms of AMPK activation. Cell Metab 11:554-565

16. Choudhury AI, Heffron H, Smith MA et al (2005) The role of insulin receptor substrate 2 in hypothalamic and B-cell function. J Clin Invest 115:940-950

17. Dabrowski M, Larsen T, Ashcroft FM, Bondo Hansen J, Wahl P (2003) Potent and selective activation of the pancreatic beta-cell type K(ATP) channel by two novel diazoxide analogues. Diabetologia 46:1375-1382

18. Hardie DG (2011) Sensing of energy and nutrients by AMPactivated protein kinase. Am J Clin Nutr 93:891S-896S

19. Hara M, Matsuda Y, Hirai K, Okumura N, Nakagawa H (1989) Characteristics of glucose transport in neuronal cells and astrocytes from rat brain in primary culture. J Neurochem 52:902-908

20. Johnson D, Shepherd RM, Gill D, Gorman T, Smith DM, Dunne MJ (2007) Glucose-dependent modulation of insulin secretion and intracellular calcium ions by GKA50, a glucokinase activator. Diabetes 56:1694-1702

21. Pellerin L (2010) Food for thought: the importance of glucose and other energy substrates for sustaining brain function under varying levels of activity. Diabetes Metab 36:S59-S63

22. Zhang C-Y, Parton LE, Ye CP et al (2006) Genipin inhibits UCP2mediated proton leak and acutely reverses obesity- and high 
glucose-induced B-cell dysfunction in isolated pancreatic islets. Cell Metab 3:417-427

23. Krauss S, Zhang C-Y, Scorrano L et al (2003) Superoxidemediated activation of uncoupling protein 2 causes pancreatic B-cell dysfunction. J Clin Invest 112:1831-1842

24. Parton LE, Ye CP, Coppari R et al (2007) Glucose sensing by POMC neurons regulates glucose homeostasis and is impaired in obesity. Nature 449:228-232

25. Zhang C, Bosch MA, Levine JE, Rønnekleiv OK, Kelly MJ (2007) Gonadotrophin-releasing hormone neurons express K(ATP) channels that are regulated by estrogen and responsive to glucose and metabolic inhibition. J Neurosci 27:10153-10164

26. Ibrahim N, Bosch MA, Smart JL et al (2003) Hypothalamic proopiomelanocortin neurons are glucose responsive and express K(ATP) channels. Endocrinology 144:1331-1340

27. Lee K, Dixon AK, Richardson PJ, Pinnock RD (1999) Glucosereceptive neurones in the rat ventromedial hypothalamus express KATP channels composed of Kir6.1 and SUR1 subunits. J Physiol 515:439-452

28. Yang XJ, Kow LM, Pfaff DW, Mobbs CV (2004) Metabolic pathways that mediate inhibition of hypothalamic neurons by glucose. Diabetes 53:67-73

29. Dunn-Meynell AA, Routh VH, Kang L, Gaspers L, Levin BE (2002) Glucokinase is the likely mediator of glucosensing in both glucose-excited and glucose-inhibited central neurons. Diabetes 51:2056-2065

30. McTaggart JS, Clark RH, Ashcroft FM (2010) The role of the KATP channel in glucose homeostasis in health and disease: more than meets the islet. J Physiol 588:3201-3209

31. Matchinsky FM (2002) Regulation of pancreatic beta-cell glucokinase: from basics to therapeutics. Diabetes 51:S394-S404

32. Thorens B (2001) GLUT2 in pancreatic and extra-pancreatic gluco-detection (review). Mol Membr Biol 18:265-273

33. Thorens B, Mueckler M (2010) Glucose transporters in the 21st century. Am J Physiol Endocrinol Metab 298:E141-E145

34. Marty N, Dallaporta M, Foretz M et al (2005) Regulation of glucagon secretion by glucose transporter type 2 (glut2) and astrocyte-dependent glucose sensors. J Clin Invest 115:545-3553

35. Wang R, Liu X, Hentges ST et al (2004) The regulation of glucoseexcited neurons in the hypothalamic arcuate nucleus by glucose and feeding-relevant peptides. Diabetes 53:1959-1965

36. Song Z, Levin B, McArdle JJ, Bakhos N, Routh VH (2001) Convergence of pre- and postsynaptic influences on glucosensing neurons in the ventromedial hypothalamic nucleus. Diabetes 50:2673-2681

37. Cotero VE, Routh VH (2009) Insulin blunts the response of glucose-excited neurons in the ventrolateral-ventromedial hypothalamic nucleus to decreased glucose. Am J Physiol Endocrinol Metab 296:E1101-E1109
38. Song Z, Routh VH (2005) Differential effects of glucose and lactate on glucosensing neurons in the ventromedial hypothalamus. Diabetes 54:15-22

39. Ainscow EK, Mirshamsi S, Tang T, Ashford ML, Rutter GA (2002) Dynamic imaging of free cytosolic ATP concentration during fuel sensing by rat hypothalamic neurones: evidence for ATP-independent control of ATP-sensitive K+channels. J Physiol 544:429-445

40. Mountjoy PD, Bailey SJ, Rutter GA (2007) Inhibition by glucose or leptin of hypothalamic neurons expressing neuropeptide $Y$ requires changes in AMP-activated protein kinase activity. Diabetologia 50:168-177

41. Murphy BA, Fakira KA, Song Z, Beuve A, Routh VH (2009) AMP-activated protein kinase and nitric oxide regulate the glucose sensitivity of ventromedial hypothalamic glucose-inhibited neurons. Am J Physiol Cell Physiol 297:C750-C758

42. Zhang C-Y, Baffy G, Perret P et al (2001) Uncoupling protein2 negatively regulates insulin secretion and is a major link between obesity, $\beta$-cell dysfunction and type 2 diabetes. Cell 105:745-755

43. Richard D, Clavel S, Huang Q, Sanchis D, Ricquier D (2001) Uncoupling protein 2 in the brain: distribution and function. Biochem Soc Trans 29:812-817

44. Kong D, Vong L, Parton LE et al (2010) Glucose stimulation of hypothalamic MCH neurons involves K(ATP) channels, is modulated by UCP2, and regulates peripheral glucose homeostasis. Cell Metab 12:545-552

45. Li LX, Skorpen F, Egeberg K, Jørgensen IH, Grill V (2002) Induction of uncoupling protein 2 mRNA in beta-cells is stimulated by oxidation of fatty acids but not by nutrient oversupply. Endocrinology 143:1371-1377

46. Wang Y, Nishi M, Doi A et al (2010) Ghrelin inhibits insulin secretion through AMPK-UCP2 pathway in beta cells. FEBS Lett 584:1503-1508

47. Calegari VC, Zoppi CC, Rezende LF, Silveira LR, Carneiro EM, Boschero AC (2011) Endurance training activates AMP-activated protein kinase, increases expression of uncoupling protein 2 and reduces insulin secretion from rat pancreatic islets. J Endocrinol 208:257-264

48. Moon H-S, Chamberland JP, Mantzoros CS (2012) Amylin and leptin activate overlapping signalling pathways in an additive manner in mouse GT1-7 hypothalamic, C2C12 muscle and AML12 liver cell lines. Diabetologia 55:215-225

49. Gloyn AL (2003) Glucokinase (GCK) mutations in hyper- and hypoglycemia: maturity-onset diabetes of the young, permanent neonatal diabetes, and hyperinsulinemia of infancy. Hum Mutat 22:353-362

50. Cerf ME (2007) High fat diet modulation of glucose sensing in the beta-cell. Med Sci Monit 13:RA12-17 